RESEARCH ARTICLE

\title{
Effect of Macronutrient Mixtures on Growth and Yield of Cotton (var. CO 14)
}

Ananthakrishnan, $\mathbf{S}^{*}$ and Backiyavathy, M.R

*Department of Soil Science \& Agricultural Chemistry, Tamil Nadu Agricultural University, Coimbatore -641 003

Received : 26 ${ }^{\text {th }}$ March, 2020

Revised : $17^{\text {th }}$ April, 2020

Revised : 06 ${ }^{\text {th }}$ May, 2020

Accepted : $25^{\text {th }}$ May, 2020

\begin{abstract}
The present study aimed to assess the effect of macronutrient mixtures on growth and yield of cotton, in farmer's field, Deenampalayam taluk of Coimbatore district, Tamil Nadu. The treatments comprised of NPK fertilizer mixtures having different nitrogenous fertilizers (urea, Calcium Nitrate (CN)), phosphatic fertilizers (Single Superphosphate (SSP)), potassic fertilizers (Muriate of Potash (MOP), Sulfate of Potash (SOP)), NP (Di-ammonium Phosphate (DAP), Mono Ammonium Phosphate (MAP), Ammonium Sulfate Phosphate (ASP)) with control. Application of CN + DAP + MOP (T5) as NPK sources to meet out the recommended dose of fertilizers for cotton registered maximum plant height $(124.9 \mathrm{~cm})$, number of sympodial branches (12.9), leaf area index (2.84), and dry matter production (8888 kg ha-1) at boll bursting stage of the crop. Highest kapas yield of $2118 \mathrm{~kg} \mathrm{ha}^{-1}$ was recorded by the treatment T5, followed by T7 (Urea + DAP + CN + SSP + MOP) (1957 $\left.\mathrm{kg} \mathrm{ha}^{-1}\right)$. Plants supplied with treatment T5 registered highest number of bolls (39.5) and boll weight $(7 \mathrm{~g})$. With regard to $\mathrm{B}: \mathrm{C}$ ratio, highest $\mathrm{B}: \mathrm{C}$ ratio of 1.70 was obtained with multiple sources of nitrogenous, phosphatic fertilizers and MOP (T7).
\end{abstract}

Keywords: Macronutrient mixture; Kapas yield; Fertilizer sources; Calcium nitrate

\section{INTRODUCTION}

Cotton, being a major cash and fibre crop has a great impact on the economy of a country. Cotton cultivation in India can be traced back to 5000 BC (Meena and Uzramma, 2017). British colonization has resulted in the growth and fall of the cotton industry in India. Raw cotton was exported from India in huge quantity and India became the largest importer of British cotton textiles. Mahatma Gandhi believed that cotton was a part of Indian self-determination, which resulted in the Khadi movement, a massive boycott of British cotton goods. Now in India, the area under cotton cultivation is 122.38 lakh ha (CAB press release, 2018). The cotton crop needs more fertilizers, plant protection chemicals, water etc. It is susceptible to a number of pests and diseases, which adds to its cost of cultivation. With regard to fertilizers, farmers usually go for straight fertilizers and mostly depend on subsidized fertilizers for supplying plant nutrients resulting in dumping of excessive fertilizers in the field. Imbalanced use of nutrients and poor nutrient management practices are the major factors that affect cotton production (Zhang et al., 2008). Macronutrient mixtures will help to supply the required nutrients in proper proportion, which improves the growth and yield of crops. Siddiqui and Oad (2007) conducted a study and found that phosphorus application in the form of DAP had resulted in increased kapas yield, leaf $P$ content, $P$ uptake and better plant growth than SSP. Jakanoor Aivalli and Backiyavathy (2019) showed that macronutrient mixture containing CAN + DAP + SOP resulted in increased growth and seed yield of red gram. With this background, the present study was conducted to find out suitable macronutrient mixture for maximizing the growth and yield of cotton.

\section{MATERIAL AND METHODS}

A field experiment was conducted in a sandy clay loam soil of farmer's field, Deenampalaym, Coimbatore during 2019-2020 with cotton variety CO 14 (origin: (MCU 5 x TCH 92-7) x MCU 5 -1, duration: 150 days). Soil sample was collected from the field and were analyzed for initial soil properties. The experimental soil belongs to Palaviduthi series (Typic Rhodustalf) and it had a pH of 7.8 and EC of $0.201 \mathrm{dS} \mathrm{m}^{-1}$. The soil was non-saline and non calcareous (Free $\mathrm{CaCO}_{3}-1.27 \%$ ) with medium organic carbon $\left(0.701 \mathrm{~g} \mathrm{~kg}^{-1}\right)$. Soil exhibited a bulk density of $1.34 \mathrm{Mg} \mathrm{m}^{-3}$. The soil was low, medium and high in NPK status (150:10:612 $\left.\mathrm{kg} \mathrm{ha}^{-1}\right)$. The 
micronutrient status was as follows : $\mathrm{Mn}: 3.40 \mathrm{ppm}$, $\mathrm{Zn}: 0.82 \mathrm{ppm}, \mathrm{Cu}: 1.20 \mathrm{ppm}$ and $\mathrm{Fe}: 5.30 \mathrm{ppm}$. The recommended dose of fertilizer for cotton variety is $80: 40: 40 \mathrm{~kg} \mathrm{NPK} \mathrm{ha-1}^{-1}$ and STCR based fertilizer recommendation by using DISSIFER software was 60:30:30 kg ha-1. Macronutrient fertilizer mixtures were prepared by physical mixing of calculated amount of specific fertilizers to meet out the recommended dose just before application. $\mathrm{N}$ sources (urea and Calcium Nitrate (CN)), P sources (Single Superphosphate (SSP)), K sources (Muriate of Potash (MOP) and Sulfate of Potash (SOP)), NP sources (Di-ammonium Phosphate (DAP), Mono Ammonium Phosphate (MAP), and Ammonium Sulfate Phosphate (ASP)) were used. The mixture was applied near to the emitters of the drip irrigation system and irrigated. The experiment was laid out in a randomized block design with nine treatments and three replications. Irrigation was provided through drip and a standard package of practices were followed as per the crop production guide, 2019. The treatments were T1 : Urea + DAP + MOP, T2: Urea + SSP + MOP, T3: Urea + DAP + SOP, T4 : Urea + MAP + SOP, T5: CN + DAP + MOP, T6 $:$ CN + $\mathrm{DAP}+\mathrm{SOP}, \mathrm{T} 7:$ Urea + DAP + CN + SSP + MOP, T8 : $\mathrm{CN}+\mathrm{ASP}+\mathrm{MOP}$ and T9 control. The plot size was $20 \mathrm{~m}^{2}(5 \mathrm{~m} \times 4 \mathrm{~m})$ and the spacing adopted was $90 \times 45 \mathrm{~cm}$. Five plants from each plot was selected randomly and tagged for measurements of growth parameters like plant height, number of sympodial branches and the number of bolls at different physiological stages of the crop viz., vegetative, flowering, boll formation and boll bursting stages. Dry matter production was calculated by cutting plants at ground level from representative plots, dried in a hot air oven at $60^{\circ} \mathrm{C}$ till constant weight was obtained and converted to $\mathrm{kg} \mathrm{ha}^{-1}$. Matured bolls from each treatment plot were weighed and expressed in gram. Leaf area index was calculated using the following formula :

$\mathrm{L} \times \mathrm{W} \times \mathrm{N} \times 0.775$

Leaf Area Index = by one plant

Where, $L$ - Length of leaf in $\mathrm{cm}$

W - Width of leaf in $\mathrm{cm}$

$\mathrm{N}$ - Number of leaves per plant

0.775 - Constant

Four pickings were made at the harvesting stage and cumulated yield per ha for individual treatments was calculated. Benefit-cost ratio was computed using following formula :

Benefit-Cost Ratio $=$ Net Profit $/$ Cost of Cultivation

Where, Net Profit = Gross Income - Cost of cultivation.

The experimental data obtained were subjected to statistical analysis (Panse and Sukhatme, 1978). Least significant difference at 0.05 probability level was used to compare differences between treatment means.

\section{RESULTS AND DISCUSSION}

\section{Plant Height}

Table 1 represents the results on plant height recorded at various physiological growth stages of cotton viz., vegetative, flowering, boll formation and boll bursting.

Table 1.Effect of macronutrient mixtures on plant height and number of sympodial branches at physiological growth stages of cotton

\begin{tabular}{|c|c|c|c|c|c|c|c|}
\hline \multirow[b]{2}{*}{ Treatment } & \multicolumn{3}{|c|}{ Plant Height (cm) } & \multirow[b]{2}{*}{$\begin{array}{c}\text { Boll } \\
\text { Bursting }\end{array}$} & \multicolumn{3}{|c|}{ Number of Sympodial Branches } \\
\hline & Vegetative & Flowering & $\begin{array}{c}\text { Boll } \\
\text { Formation }\end{array}$ & & Flowering & $\begin{array}{c}\text { Boll } \\
\text { Formation }\end{array}$ & $\begin{array}{c}\text { Boll } \\
\text { Bursting }\end{array}$ \\
\hline $\mathrm{T} 1$ - Urea + DAP + MOP & 27.2 & 53.0 & 100.7 & 116.3 & 5.6 & 9.1 & 10.0 \\
\hline $\mathrm{T} 2$ - Urea + SSP +MOP & 27.3 & 53.5 & 102.1 & 117.3 & 5.7 & 9.3 & 10.2 \\
\hline T3 - Urea + DAP + SOP & 27.0 & 48.6 & 94.7 & 111.2 & 5.3 & 8.8 & 9.40 \\
\hline $\mathrm{T} 4$ - Urea + MAP + SOP & 26.5 & 47.1 & 93.7 & 111.0 & 5.0 & 8.5 & 9.30 \\
\hline T5 - CN + DAP+MOP & 34.6 & 64.2 & 112.5 & 124.9 & 6.7 & 11.4 & 12.9 \\
\hline $\mathrm{T} 6-\mathrm{CN}+\mathrm{DAP}+\mathrm{SOP}$ & 27.5 & 56.3 & 105.3 & 120.8 & 5.7 & 10.5 & 11.0 \\
\hline $\begin{array}{l}\text { T7 - Urea + DAP + CN + SSP } \\
+ \text { MOP }\end{array}$ & 30.6 & 59.5 & 108.8 & 121.3 & 6.3 & 11.1 & 11.8 \\
\hline T8 - CN+ASP+MOP & 28.9 & 59.3 & 106.4 & 121.1 & 5.8 & 11.1 & 11.5 \\
\hline T9 - Control & 24.3 & 44.5 & 82.7 & 98.2 & 4.3 & 7.9 & 8.80 \\
\hline SEd & 0.46 & 1.07 & 2.09 & 2.24 & 0.10 & 0.15 & 0.21 \\
\hline$C D(p=0.05)$ & 0.98 & 2.26 & 4.43 & 4.75 & 0.22 & 0.32 & 0.46 \\
\hline
\end{tabular}


The results revealed that there was a significant difference in plant height among the treatments at vegetative and flowering stages of the crop. At boll formation and boll bursting stages, the treatments gave on par results.
At vegetative stage, application of $\mathrm{CN}+\mathrm{DAP}$ + MOP (T5) registered the highest plant height of $34.6 \mathrm{~cm}$ which was followed by Urea + DAP + CN $+\mathrm{SSP}+\mathrm{MOP}(30.6 \mathrm{~cm})(\mathrm{T} 7)$ and $\mathrm{CN}+\mathrm{ASP}+\mathrm{MOP}$ $(28.9 \mathrm{~cm})(\mathrm{T} 8)$.

Table 2. Effect of macronutrient mixtures on kapas yield and benefit-cost ratio of cotton

\begin{tabular}{lrr}
\hline Treatment & Kapas yield $\left(\mathrm{kg} \mathrm{ha}^{-1}\right)$ & B:C Ratio \\
\hline T1 - Urea + DAP + MOP & 1747 & 1.65 \\
T2 - Urea + SSP +MOP & 1780 & 1.69 \\
T3 - Urea + DAP + SOP & 1442 & 1.29 \\
T4 - Urea + MAP + SOP & 1414 & 1.19 \\
T5 - CN + DAP+MOP & 2118 & 1.69 \\
T6 - CN+DAP+SOP & 1929 & 1.46 \\
T7 - Urea + DAP + CN + SSP + MOP & 1.70 \\
T8 - CN+ASP+MOP & 1957 & 1.62 \\
T9 - Control & 1948 & 1.26 \\
SEd & 1270 & - \\
CD $(p=0.05)$ & 37.09 & - \\
\hline
\end{tabular}

The minimum value of 24.3 was recorded by the control treatment. A similar trend of results was observed at the flowering stage also. At both stages, the treatment T5 showed $26.84 \%$ (vegetative stage) and $20.01 \%$ (Flowering stage) increase in plant height over the standard check (T2). Nitrogen is the most important nutrient in increasing the growth of the crop (Weinhold et al., 1995). Calcium nitrate application would have improved the physical condition of the soil and led to increasing the nitrogen use efficiency. In addition, the nitrate present in the fertilizer is readily available to the crop without any conversion, which would have been enhanced the initial crop growth immediately after establishment. Plant height is directly proportional to the increasing rates of nitrogen applied at various crop growth stages (Ali and Hameed, 2011). Souri and Dehnavard (2018) reported similar findings and they found that plant height in tomato was significantly higher in plants treated with calcium nitrate as compared to that of urea and ammonium sulfate.

\section{Sympodial Branches}

Sympodium refers to fruiting branch of the cotton crop. The results on number of sympodial branches at various physiological growth stages of cotton are presented in Table 1. Significant difference among number of symbodial branches were observed at flowering and boll bursting stages, whereas at boll formation stage, on par results were observed.

The highest mean value for sympodial branches was observed in the treatment T5 $(\mathrm{CN}+\mathrm{DAP}+$ MOP) (6.7) followed by T7 (Urea + DAP + CN + SSP + MOP) (6.3) and control recorded minimum (4.3) at flowering stage. A similar trend was observed in the boll bursting stage, whereas no significant difference was observed in boll formation stage. Nitrogen is responsible for vegetative growth in plants. The number of sympodial branches increased with an increase in N level (Abbasi and Abro, 2002 ; Baraich et al., 2012). Plot fertilized with calcium nitrate as $\mathrm{N}$ source recorded the maximum number of sympodial branches. In addition, plant height has a positive correlation with the number of sympodial branches (Hussein et al., 2000).

\section{Leaf Area Index (LAI)}

There was a significant difference between treatments for leaf area index. At vegetative stage application of treatment CN + DAP + MOP (T5) recorded highest value $(0.24)$ which was followed by Urea + DAP + CN + SSP + MOP (T7) (0.19) and $\mathrm{CN}+\mathrm{ASP}+\mathrm{MOP}(\mathrm{T} 8)(0.19)$, which were on par. Lowest LAI was recorded in the control treatment (T9) (0.07) (Fig. 3). At the flowering stage, the treatment with T5 registered the highest value of 2.40 . The second highest value for LAl was recorded by T8 (1.97) and T7 (1.95) treatments, which were on par. The lowest value was recorded in the control treatment (T9) (0.57). Similar trends of results were registered in the following stages. Abbasi (2012) showed that calcium ammonium nitrate and ammonium sulfate treated plants showed higher LAI because it supplied both $\mathrm{NH}^{4+}$ and $\mathrm{NO}^{3-}$ form of nitrogen. Similar results were recorded in the present study.

\section{Dry matter production}

The results of dry matter production increased from stage to stage (Fig. 4). Dry matter production among treatments during vegetative and boll formation stages were found to be on par.

$107|4-6| 206$ 
A significant difference in dry matter production was observed during the flowering stage and boll bursting stage. At flowering stage, treatment T5 (1091 kg ha ${ }^{-1}$ ) was found to be superior, which was followed by treatment T7 (953 kg ha-1). A similar trend was observed during boll bursting stage, with T5 (8888 kg ha-1) and T7 (8592 kg ha $\left.{ }^{-1}\right)$. Results obtained in the present study were consistent with those reported by Abbasi (2012) where source containing ammonium nitrate recorded higher dry matter production than urea supplied maize plants. In the present study, fertilizer mixture containing both ammonium and nitrate fraction resulted in higher DMP.

\section{Boll weight}

Fig. 1 represents the mean weight of mature cotton bolls. Treatment T5 recorded the highest single boll weight (7g), followed by T7 (6.9 g), T6 (6.8 g) and T8 (6.8 g), which were all on par. Control (T9) recorded the lowest boll weight of 5.0 g. Sawan et al. (1997) confirmed that calcium concentrations have a significant role in increasing cotton boll weight. Our study showed similar results.

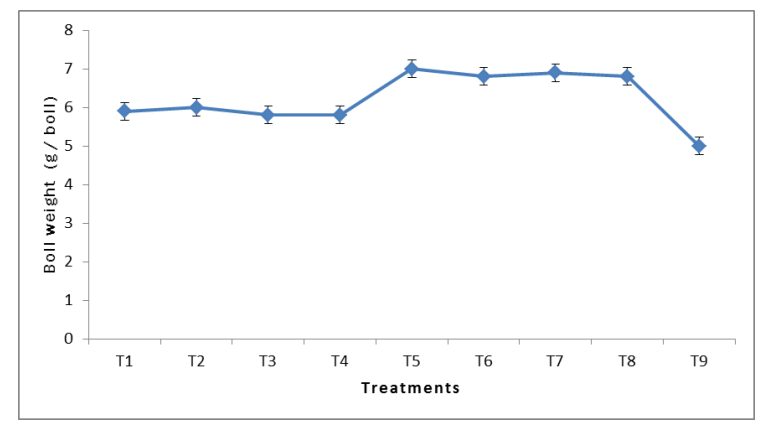

Figure 1. Effect of macronutrient mixtures on boll weight of cotton

\section{Number of bolls}

Significant differences were observed among the number of bolls per plant and the results showed that the highest number of bolls per plant was recorded in the plot fertilized with treatment T5, which was followed by treatment T7 and T8, which were on par (Figure 2).

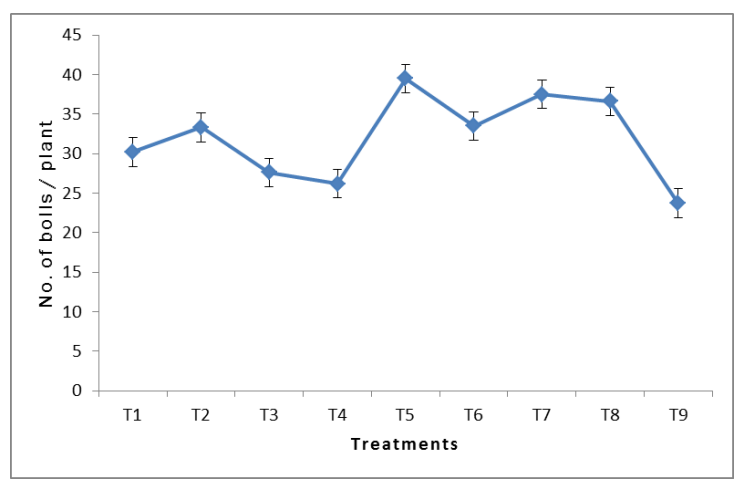

Figure 2. Effect of macronutrient mixtures on number of bolls per plant of cotton
Calcium helps to increase the number of opened bolls per plant (Sawan et al., 1997) and Addicott and Lyon (1973) showed that calcium inhibited square and boll abscission in cotton. It is clear from Table 3 that $\mathrm{Ca}$ containing treatments have resulted in plants with a higher number of bolls.

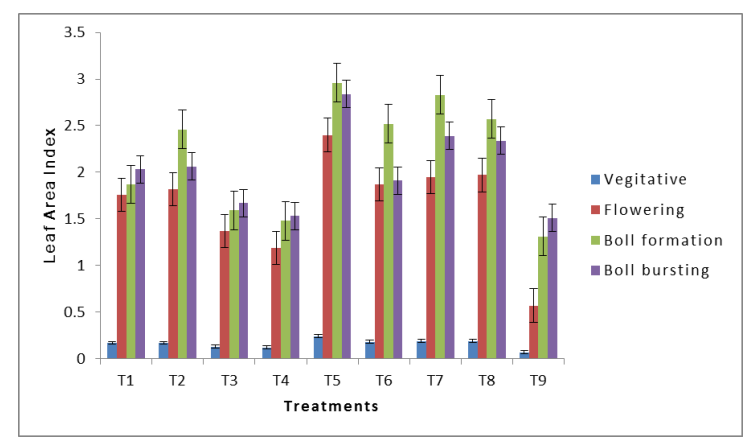

Figure 3. Effect of macronutrient mixtures on Leaf Area Index (LAI) at physiological growth stages of cotton

\section{Kapas Yield}

The results on kapas yield of cotton (Table 4) indicated that the crop responded differently to different combinations of nutrient mixtures. Sympodial branches indirectly have a great effect on increasing kapas yield per plant through the number of bolls (Salahuddin et al., 2010; Hussein et al., 2000). Plant height and number of sympodial branches had a positive correlation with yield (Ganesan and Raveendran, 2010). Similar responses were observed in this study. A significant difference in yield was observed with different treatments, where the highest value resulted from the application of macronutrient mixture, $\mathrm{CN}+\mathrm{DAP}+\mathrm{MOP}$ (T5) (2118 kg ha-1) and lowest value was recorded in control (1270 kg ha-1).

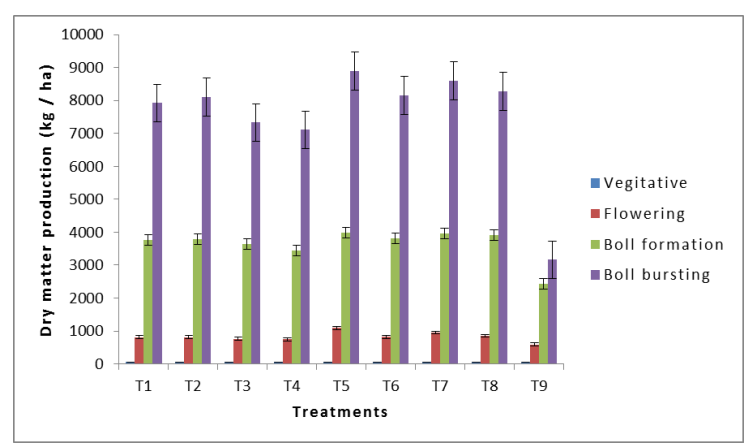

Figure 4. Effect of macronutrient mixtures on dry matter production at physiological growth stages of cotton

Cotton roots can take up both nitrate and ammonium ions for the physiological processes that drive crop development and yield (National Cotton Council, 1994). Calcium nitrate provides nitrogen in nitrate form, whereas DAP provides nitrogen in the ammoniacal form: two plant-available forms of nitrogen. This also helps to maintain healthy $\mathrm{pH}$ of 
the soil as the presence of ammonium ion tends to decrease the $\mathrm{pH}$, whereas nitrate form tends to increase it. Potassium increased the activity of the cytochrome oxidase and nitrate reductase, which improved the stomatal conductance and decreased the transpiration rates; these are the physiological effects of $\mathrm{K}^{+}$. Potassium application also increased lint yield and improved cotton and seed quality ( $\mathrm{Xi}$, 1989). Potassium improved nitrogen absorption owing to increased vegetative growth (Ali and Tatla, 2007). Plots fertilized with MOP recorded more yield compared to the plots fertilized with SOP. This confirmed the results of Keshavarz et al. (2004), who noted that the maximum yield of cotton in saline condition was obtained by using SOP and in non-saline condition by MOP (10\% yield increase as compared to SOP). In the present study, treatment T5 recorded $18.99 \%$ increase in yield over the standard check (T2). This was followed by T7 with a percentage increase of $9.94 \%$ over the standard check (T2).

\section{Benefit-Cost Ratio}

The benefit-cost ratio ranged from 1.26 to 1.70 (Table 4). Highest B:C ratio was observed for treatment combination, Urea + DAP + CN + SSP + MOP (T7) (1.70). Treatment T7 comprised three sources for $\mathrm{N}$ (Urea, DAP and $\mathrm{CN}$ ) and two sources of $\mathrm{P}$ (DAP, SSP), which reduced the total fertilizer cost and resulted in higher yield. In case of treatment T5, even though the yield was higher, the cost of the fertilizers resulted in lower B:C ratio (1.69). Thus, T7 was found to be a more economical and feasible macronutrient mixture followed by treatment T2 (1.69) and treatment T5 (1.69). However, it was found that calcium-containing macronutrient mixtures showed a higher yield.

\section{CONCLUSION}

The present study showed that the application of macronutrient mixtures containing calcium nitrate significantly improved the growth attributes and increased the kapas yield of cotton. Calcium nitrate present in the fertilizer mixture helped in increasing the nutrient uptake by creating a better physical condition of the soil, particularly soil structure. Hence, kapas yield of cotton was highest in the treatment T5 $(\mathrm{CN})$, which was $18.99 \%$ over the standard check (Urea + SSP + MOP) (T2). It was also clear from the results that combining different sources of nitrogenous and phosphatic fertilizers had a great impact on the yield of cotton crops. With respect to $\mathrm{B}: \mathrm{C}$ ratio, this treatment, $\mathrm{T} 7$ was economically feasible with a BCR of 1.70.

\section{REFERENCES}

Abbasi, Z. A. and M. B. Abro. 2002. Growth response of cotton cultivars under different NP fertilizer levels. Pak. J. Appl. Sci., 2 (4): 494-496.

$107|4-6| 208$
Addicott, F.T. and Lyon, J.L. Physiological Ecology of Abscission. In Shedding of Plant Parts; Kozlowski, T. T., Ed.; Academic Press: New York, 1973. 85-124

Aivalli, J.B. and Backiyavathy, M.R. 2019. Effect of Crop Specific Nutrient Mixtures on Growth, Yield attributes and Yield of Redgram (Cajanus cajan L.) under Irrigated Condition. Madras Agricultural Journal, 106.

Ali, M.A. and Tatla, Y. H. 2007. RESPONSE OF COTTON (Gossypium hirsutum L.) TO. J. Agric. Res, 45(3): 191-196.

Ali, H., and Hameed, R.A. 2011. Growth, yield and yield components of American cotton (Gossypium hirsutum L.) as affected by cultivars and nitrogen fertilizer. Chemical analysis., 15: 30.

Baraich, A. A. K., Baraich, A. H. K., Jamali, L. A. and Salarzi, A.U. 2012. Effect of nitrogen application rates on growth and yield of cotton varieties. Pakistan Journal of Agriculture, Agricultural Engineering and Veterinary Sciences., 28: 115-123.

CAB. 2018 November 22. Area and Production Estimated by the Cotton Advisory Board on 22.11.2018 for Cotton Season 2017-18 and 2018-19 (Provisional) [Press Release]. Retrieved from http://www. caionline.in/articles/cotton-advisory-board-cabpegs-2018-19-cotton-crop-at-36-1-mln-bales

CPG, 2019. Crop Production Guide. Dept. of Agriculture, Govt. of Tamil Nadu, Chennai \& Tamil Nadu Agricultural University, Coimbatore, Tamil Nadu.

Ganesan, K.N. and Raveendran, T.S. 2010. Selection parameters for improving the seed cotton yield and fiber quality traits in American Cotton (Gossypium hirsutum L.). Electron. J. Plant Breed. 1(3): 279-286.

Hussein, S.S., Azhar, F.M. and Mahmood, I. 2000. Path Coefficient and Correlation Analysis of Some Important Plant Traits of Gossypium hirsutum L. Pakistan Journal of Biological Sciences, 3(9): 1399-1400.

Keshavarz, P., Norihoseini, M. and Malakouti, M.J. 2004. Effect of soil salinity on $\mathrm{K}$ critical level for cotton and its response to sources and rates of $\mathrm{K}$ Fertilizers. IPI regional workshop on Potassium and Fertigation development in West Asia and North Africa.,: 24-28.

Meena Menon and Uzramma. 2017. A Frayed History: The Journey of Cotton in India. Oxford University Press. ISBN 9780199091492: 29.

National Cotton Council. 1994. Newsletter of the Cotton Physiology Education Program (Vol. 5, No. 4) [PDF file] Memphis: Cotton Physiology Today. Retrieved from https://www.cotton.org/tech/physiology/cpt/ fertility/upload/CPT-May94-REPOP.pdf

Panse, V.C. and Sukhatme, P.V. 1978. Statistical methods for Agricultural workers. III Rev. Ed. ICAR, New Delhi.

Salahuddin, S., Abro, S., Kandhro, M.M., Salahuddin, L. and Laghari, S. 2010. Correlation and path coefficient analysis of yield components of upland cotton (Gossypium hirsutum L.) sympodial. World Applied Sciences Journal, 8: 71-75. 
Sawan, Z.M., Mahmoud, M.H. and Momtaz, O. A. 1997. Effect of phosphorus fertilization and foliar application of chelated zinc and calcium on quantitative and qualitative properties of Egyptian cotton (Gossypium barbadense L. Var. Giza 75). Journal of Agricultural and Food Chemistry, 45(8): 3326-3330.

Souri, M. K. and Dehnavard, S. 2018. Tomato plant growth, leaf nutrient concentrations and fruit quality under nitrogen foliar applications. Advances in Horticultural Science., 32(1): 41-47.

Siddiqui, M. H. and Oad, F.C. (2007). Performance of phosphorus sources in cotton crop. Proceedings Soils 2007: Peat and Other Soil Factors in Crop Production.
Wahid, M. A., Cheema, M. A., Malik, M. A. and Ashraf, Muhammad. 2009. Comparative performance of canola hybrids in response to different phosphatic fertilizers. International Journal of Agriculture Biology., 11: 306-310.

Weinhold, B.J., P.T. Todd and G.A. Reichman. 1995. Yield and nitrogen efficiency of irrigated corn in Northern Great plains. Agronomy Journal., 87: 842-846.

Xi, S., Lihua, R., Yongsong, Z., Qizhao, Y., Caixian, T. and Lianxiang, Q. 1989. Effect of potassium fertilizer application on physiological parameters and yield of cotton grown on a potassium deficient soil. Zeitschrift für Pflanzenernährung und Bodenkunde., 152(3): 269-272.

Zhang, Y., W. Hu, Y. Gao, Y. Yao, M. Tang and G. Hu. 2008. Fertilizing irrigated cotton for high yield and high nitrogen use efficiency. Better Crops with Plant Food., 92(4): 6-7. 